medRxiv preprint doi: https://doi.org/10.1101/2021.10.01.21264398; this version posted October 1, 2021. The copyright holder for this preprint (which was not certified by peer review) is the author/funder, who has granted medRxiv a license to display the preprint in

All rights reserved. No reuse allowed without permission.

\title{
Symptom Monitoring based on Digital Data Collection During Inpatient Treatment of Schizophrenia Spectrum Disorders - a Feasibility Study
}

Julian Herpertz ${ }^{1}$, Maike Frederike Richter ${ }^{1}$, Carlotta Barkhau ${ }^{1}$, Michael Storck ${ }^{2}$, Rogério

Blitz $^{1,2}$, Lavinia A. Steinmann ${ }^{1}$, Janik Goltermann ${ }^{1}$, Udo Dannlowski ${ }^{1}$, Bernhard T. Baune $^{3,4,5}$, Julian Varghese ${ }^{2}$, Martin Dugas ${ }^{2,6}$, Rebekka Lencer ${ }^{1,7}$, Nils Opel ${ }^{1,8}$ *

\section{Affiliations}

1 Institute for Translational Psychiatry, University of Münster, Münster, Germany

2 Institute of Medical Informatics, University of Münster, Münster, Germany

3 Department of Psychiatry, University of Münster, Münster, Germany

4 Department of Psychiatry, Melbourne Medical School, The University of Melbourne, Melbourne, Australia

5 The Florey Institute of Neuroscience and Mental Health, The University of Melbourne Parkville, Melbourne, Australia

6 Institute of Medical Informatics, Heidelberg University Hospital, Heidelberg, Germany

7 Department of Psychiatry and Psychotherapy, University of Lübeck, Lübeck, Germany

8 Interdisciplinary Centre for Clinical Research Münster, University of Münster, Münster, Germany

*This is to indicate that RL and NO contributed equally to the present work and should therefore both be considered senior author.

\section{Correspondence:}

N. Opel, Department of Psychiatry, University of Münster, Albert-Schweitzer-Str. 11, 48149 Münster, Germany, Phone: ++49-251-8358160, Email: n_opel01 [at] uni-muenster.de

Keywords: Schizophrenia spectrum disorder, digital data collection, feasibility study, selfreports psychiatry

NOTE: This preprint reports new research that has not been certified by peer review and should not be used to guide clinical practice. 
medRxiv preprint doi: https://doi.org/10.1101/2021.10.01.21264398; this version posted October 1, 2021. The copyright holder for this preprint (which was not certified by peer review) is the author/funder, who has granted medRxiv a license to display the preprint in

All rights reserved. No reuse allowed without permission.

\begin{abstract}
Background: Digital acquisition of risk factors and symptoms based on patients' self-reports represents a promising, cost-efficient and increasingly prevalent approach for standardized data collection in psychiatric clinical routine. While the feasibility of digital data collection has been demonstrated across a range of psychiatric disorders, studies investigating digital data collection in schizophrenia spectrum disorder patients are scarce. Hence, up to now our knowledge about the acceptability and feasibility of digital data collection in patients with a schizophrenia spectrum disorder remains critically limited.
\end{abstract}

Objective: The objective of this study was to explore the acceptance towards and performance with digitally acquired assessments of risk and symptom profiles in patients with a schizophrenia spectrum disorder in comparison with patients with an affective disorder.

Methods: We investigated the acceptance, the required support and the data entry pace of patients during a longitudinal digital data collection system of risk and symptom profiles using self-reports on tablet computers throughout inpatient treatment in patients with a schizophrenia spectrum disorder. As a benchmark comparison, findings in patients with schizophrenia spectrum disorder were evaluated in direct comparison with findings in affective disorder patients. The influence of sociodemographic data and clinical characteristics on the assessment was explored. The study was performed at the Department of Psychiatry at the University of Münster between February 2020 and February 2021.

Results: Of 82 patients diagnosed with a schizophrenia spectrum disorder who were eligible for inclusion $59.8 \%(n=49)$ agreed to participate in the study of whom $54.2 \%(n=26)$ could enter data without any assistance. Inclusion rates, drop-out rates and subjective experience ratings did not differ between patients with a schizophrenia spectrum disorder and patients with an affective disorder. Out of all participating patients, 98\% reported high satisfaction with the digital assessment. Patients with a schizophrenia spectrum disorder needed more support and more time for the assessment compared to patients with an affective disorder. The extent of support of patients with a schizophrenia spectrum disorder was predicted by age, whereas the feeling of self-efficacy predicted data entry pace.

Conclusion: Our results indicate that, although patients with a schizophrenia spectrum disorder need more support and more time for data entry than patients with an affective disorder, digital data collection using patients' self-reports is a feasible and well-received method. Future clinical and research efforts on digitized assessments in psychiatry should 
medRxiv preprint doi: https://doi.org/10.1101/2021.10.01.21264398; this version posted October 1 , 2021. The copyright holder for this preprint (which was not certified by peer review) is the author/funder, who has granted medRxiv a license to display the preprint in All rights reserved. No reuse allowed without permission.

include patients with a schizophrenia spectrum disorder and offer adequate support to reduce digital exclusion of these patients.

\section{Introduction}

Schizophrenia spectrum disorders (SSDs) comprise psychiatric diagnoses such as schizophrenia, schizoaffective disorder, schizotypal and delusional disorder which are described in ICD 10 in sections F20.0 through F29.9 (World Health Organization, 1993). Schizophrenia as the most relevant disorder of this spectrum is a frequently chronic psychiatric disorder with a life-time prevalence of almost one percent (Kahn et al., 2015). In spite of a relatively low prevalence it is among the world's top ten reasons for long-term disability (Mueser \& Mcgurk, 2004) which, in addition to its impact on the individual, highlights the large economic and societal burden of this disorder. Successful treatment is difficult due to the considerable heterogeneity of the clinical picture of patients with a schizophrenic spectrum disorder (PSSD). It has long been considered as a syndrome consisting of different subtypes (Ahmed et al., 2018; Buchanan RW, 1994). There is a high susceptibility to relapse in schizophrenia. Forty percent of inpatients suffer from a relapse within one year even though they received appropriate therapy (Barnett et al., 2018) and each new episode increases the risk of chronicity (Alvarez-Jimenez et al., 2012). Hence, it has been suggested that detailed information on risk and symptom profiles might help to identify patients that are particularly vulnerable to relapse (Habtewold et al., 2020). The implementation of data collections during inpatient treatment for schizophrenia could help to quantify symptom development and treatment response. This would allow for the partial decryption of the disorder and identify patients that are at great risk to relapse (Henson et al., 2021; Torous et al., 2018). Ideally, this data is assessed digitally as it can be stored directly in the patient's electronic medical record and the clinical staff has a direct access to the patients' 
medRxiv preprint doi: https://doi.org/10.1101/2021.10.01.21264398; this version posted October 1 , 2021. The copyright holder for this preprint (which was not certified by peer review) is the author/funder, who has granted medRxiv a license to display the preprint in All rights reserved. No reuse allowed without permission.

information. Many therapeutic processes can be accelerated and practitioners are offered a chance to get a holistic understanding of their patients' health (Hsin et al., 2018; Mehta et al., 2019; Rojnic Kuzman et al., 2018).

There are plenty of ways to use digital data in psychiatry, still the usage of digital resources is little (Myin-Germeys, 2020) and we are still early in the process of converting from paper to a digital based medicine (Torous \& Baker, 2016). Big data approaches in psychiatry face particular challenges, as their implementation relies on the clinicians but also strongly on the participation of patients (Monteith et al., 2016). Certain relevant information on mood, affective state or psychotic symptom severity cannot be assessed externally and must therefore be provided by the patients themselves. Self-reports gain ground, as they enable to actively participate in research efforts (Sartorius, 2014). Presented in a digital format they can be used to collect data in a location- and time-variable manner. Compared to classic paper questionnaires, digital assessment tools are of similarly high reliability (Alfonsson et al., 2014; Hsin et al., 2018). They are more cost-saving (Kuzman et al., 2017; Marcano Belisario et al., 2014) and have been shown to be preferred among medical staff as well as nonpsychiatric patients (Fritz et al., 2012). Touchscreen modules in particular are gaining increasing acceptance (Preuschoff et al., 2013). We have already established a patientreported outcomes system at the University Hospital Münster and showed its validity in patients with an affective disorder (PADs; Richter et al., 2020).

PSSDs however are often not trusted with handling the digital opportunities that come with our time. Concerns exist about the user engagement (Ben-Zeev et al., 2016; Daker-White \& Rogers, 2013; Surmann et al., 2017) and that cognitive impairment may complicate the use of assistive technologies (Surmann \& Lencer, 2017; Treisman et al., 2016). As a consequence patients find themselves digitally excluded with less use of computers, mobile phones and the internet (Greer et al., 2019; Wong et al., 2020). This led Firth and Torous (2015) to state that 
medRxiv preprint doi: https://doi.org/10.1101/2021.10.01.21264398; this version posted October 1 , 2021. The copyright holder for this preprint (which was not certified by peer review) is the author/funder, who has granted medRxiv a license to display the preprint in All rights reserved. No reuse allowed without permission.

PSSDs face a double stigma based on the nature of their condition on the one hand, and attitudes toward their abilities to handle digital media on the other. According to Robotham (2016) there still seems to exist a "digital divide" with the risk that PSSDs benefit less from digitalization than other patient groups. It is suggested that four out of five patients with schizophrenia and related psychoses would not fit criteria to enroll in a typical treatment research study (Humphreys, 2017) demonstrating a considerable selection bias and systematic exclusion of more acutely ill PSSDs from research efforts. The development towards a more digitized psychiatry bears the risk that PSSDs are excluded even more from progresses in research (Kidd et al., 2019; Robotham et al., 2016; Treisman et al., 2016).

Furthermore it could be expected that a paranoia towards digital media lies within the nature of PSSDs (McLaren et al., 1995; Santesteban-Echarri et al., 2020; Treisman et al., 2016). Patients with severe mental health problems seem to be at risk of misinterpreting the virtual world and suffer from paranoia after the use of social media for instance ( Berry et al., 2018). However, current research indicates that there seems to be willingness and desire of patients to integrate digital tools in their everyday life (Ben-Zeev et al., 2013; Berry et al., 2019; Bucci et al., 2018).

Yet, only few studies have examined the applicability with PSSDs, whether for complex data collection or digital interventions (Barnett et al., 2018; Kidd et al., 2019; Liu et al., 2019; Tolley et al., 2015). Previous studies are characterized by small samples of psychopathologically stable patients and have typically focused on outpatients. Furthermore, research efforts did not include insights about the patients' subjective experience with the digital medium. While there are studies exploring the perception of medical staff towards digital data assessments in psychiatry (Aref-Adib et al., 2020; Odendaal et al., 2020), to the best of our knowledge, no validated psychometric instrument exists for the assessment of PSSDs' subjective experience with digital data collections in clinical routine. 
medRxiv preprint doi: https://doi.org/10.1101/2021.10.01.21264398; this version posted October 1, 2021. The copyright holder for this preprint (which was not certified by peer review) is the author/funder, who has granted medRxiv a license to display the preprint in All rights reserved. No reuse allowed without permission.

In spite of the existing stigmas, we hypothesize that the digital exclusion of PSSDs is to further extent unjustified. To test this hypothesis, the present controlled feasibility study investigates the applicability of a longitudinal digital data assessment with the help of a tablet computer during inpatient treatment of PSSDs. We investigated the acceptance, the level of support and the time required to perform the data entry. Results are compared to those of PADs. Lastly sociodemographic and psychometric factors on the handling of the tablet of PSSDs are considered.

\section{Methods}

\section{Sample}

A total of 182 inpatients of the Department of Psychiatry, University Hospital Münster, was approached and asked to participate in the study between February 2020 and February 2021. Criteria for inclusion were a diagnosis of schizophrenia, a schizoaffective, a schizotypal, delusional and other non-mood psychotic (F20.0 through F29.9) or affective (F30.0 through F39.9, ICD-10) disorder and sufficient German language knowledge. Please refer to Table S1 and Table S2 for further information on the participants' diagnoses. The study was approved by the institutional review board of the Medical Faculty, University of Münster, and written informed consent was obtained from every patient. We predefined reasons for exclusion: organizational reasons, exclusion by clinicians because of severe cognitive deficits or mental instability that would hinder participation and insufficient German language knowledge.

\section{Procedure}

We aimed to achieve a number of 100 participating patients and proceeded recruitment until we included 49 PSSDs and 51 PADs. The recruitment steps followed procedures described in our previous work (Richter et al., 2020). Patients with the appropriate diagnosis were identified through a patient recruitment system based on the diagnosis entered into the 
medRxiv preprint doi: https://doi.org/10.1101/2021.10.01.21264398; this version posted October 1, 2021. The copyright holder for this preprint (which was not certified by peer review) is the author/funder, who has granted medRxiv a license to display the preprint in

All rights reserved. No reuse allowed without permission.

electronic health record by the attending physician at admission. Patients were informed in detail about the study's main objective (digital assessment of risk and resilience factors for relapse and chronification) and were invited to answer tablet-based questions every other week during their hospital stay. Patients were also informed that the clinical staff had access to their answers.

The tablet-based baseline assessment included self-report questionnaires on sociodemographic data, personal and family mental health history, the Childhood Trauma Questionnaire (CTQ, Bernstein et al., 1997), the Big Five Inventory (BFI, Soto \& John, 2017), the Self-Efficacy Scale (SES, Luszczynska et al., 2005) and Beck's Depression Inventory (BDI, Beck et al., 1960). The Hamilton Depression Scale (HAMD, Hamilton, 1960), the Global Assessment of Functioning (GAF, Hall, 1995) and the Positive and Negative Syndrome Scale (PANSS, Kay et al., 1987) were additionally carried out by trained research assistants. Patients entered data via the Mobile Patient Survey, a web-based multilanguage electronic patient-reported outcome system (Soto-Rey et al., 2017) on an Apple iPad tablet. Completed data entries were added automatically to the electronic health record. The technical infrastructure for data acquisition, storage and export implemented at the Department of Psychiatry and Psychotherapy has been extensively described in our previous work (Blitz et al., 2021). Finally, patients were asked to evaluate their own performance and contentment regarding the handling of the tablet questionnaire (Table 1).

\section{Acceptance}

Due to the absence of a validated psychometric instrument, we developed a novel questionnaire to assess subjective user experience at baseline assessment as well as previous experience with digital health applications. More concretely, to assess patients' subjective experience of the digital assessment, patients were asked about prior experience with mental health smartphone applications and tablet use, about their individual difficulties 
medRxiv preprint doi: https://doi.org/10.1101/2021.10.01.21264398; this version posted October 1 , 2021. The copyright holder for this preprint (which was not certified by peer review) is the author/funder, who has granted medRxiv a license to display the preprint in

All rights reserved. No reuse allowed without permission.

understanding and answering the questions on the tablet and whether they were interested in integrating similar questionnaires into their everyday life by means of a smartphone application (Table 1). These data were assessed in form of a paper-pencil questionnaire after data entry.

Based on the questions 3 to 7 (Table 1) and a 4-point Likert-scale (very easy/definitely=4; very difficult/not at all=1) a sum-score (Tablet-experience score) was created with 20 as the highest and 5 as the lowest score. The total score gives an estimate about how well the patient understands and answers the questions. The internal consistency of the score was satisfying with a Cronbach's alpha of .84 .

Table 1: Questionnaire asking about the patient's subjective experience with the assessment using a tablet

\begin{tabular}{|c|c|c|c|}
\hline Question & Answer & $\begin{array}{l}\text { Schizophrenia } \\
\text { spectrum } \\
\text { disorder }(\mathrm{N}=47)\end{array}$ & $\begin{array}{l}\text { Affective } \\
\text { disorder } \\
(\mathrm{N}=50)\end{array}$ \\
\hline & & Frequency $(\%)$ & Frequency $(\%)$ \\
\hline 1 Do you use an eHealth & Yes & $8(17)$ & $7(14)$ \\
\hline application? & No & $39(83)$ & $43(86)$ \\
\hline 2 Do you have experiences with & Yes & $29(62)$ & $40(80)$ \\
\hline handling a tablet device? & No & $18(38)$ & $10(20)$ \\
\hline 3 How easy was it to understand & Very Easy & $19(40)$ & $26(52)$ \\
\hline \multirow[t]{2}{*}{ the questions? } & Easy & $22(47)$ & $20(40)$ \\
\hline & Difficult & $6(13)$ & $4(8)$ \\
\hline
\end{tabular}


medRxiv preprint doi: https://doi.org/10.1101/2021.10.01.21264398; this version posted October 1, 2021. The copyright holder for this preprint (which was not certified by peer review) is the author/funder, who has granted medRxiv a license to display the preprint in All rights reserved. No reuse allowed without permission.

4 How easy was it to answer the questions?

5 Could you concentrate well during the data entry?

6 Would you feel comfortable answering the questions without any support?
Very Difficult

Very Easy

Easy

Difficult

Very Difficult

Strongly agree

Agree

Disagree

Strongly disagree

$0(0)$

$0(0)$

$20(43)$

$25(53)$

$2(4)$

$0(0)$

$0(0)$

$20(40)$

$3(6)$

$0(0)$

Strongly agree

$25(53)$

$26(52)$

Agree

$14(30)$

$22(44)$

Disagree

8 (17)

$2(4)$

Strongly disagree $\quad 0(0)$

$0(0)$

7 Did you feel secure with handling Strongly agree

$27(57)$ the tablet device?

Agree

$17(36)$

$18(36)$

Disagree

$2(4)$

$1(2)$

Strongly disagree

$1(2)$

$0(0)$

8 Do you prefer a digital

Strongly agree

$23(49)$

$19(38)$

questionnaire to a pen and paper

Agree

$16(34)$

$25(50)$ 
medRxiv preprint doi: https://doi.org/10.1101/2021.10.01.21264398; this version posted October 1, 2021. The copyright holder for this preprint (which was not certified by peer review) is the author/funder, who has granted medRxiv a license to display the preprint in All rights reserved. No reuse allowed without permission.

questionnaire?

Disagree

Strongly disagree

Very satisfied

Satisfied

Unsatisfied

Very unsatisfied

Strongly agree

$16(34)$

Agree

$18(38)$

$10(21)$

Disagree

Strongly disagree

$3(6)$
7 (15)

$1(2)$

$24(51)$

$22(47)$

$1(2)$

$0(0)$

$0(0)$

life? an eHealth application into your

The questions three to seven were summed up to form the Tablet-experience score.

Two patients with a schizophrenia spectrum disorder and one patient with an affective disorder did not fill out the questionnaire after data entry due to concentration problems.

We performed a linear regression model to assess the influence of age, gender, depressive symptom expression, the level of functioning and self-efficacy on the Tablet-experience score of PSSDs. Age, gender, the baseline sum scores of BDI, HAMD, GAF and SES served as independent variables while the Tablet-experience score served as the dependent variable.

\section{Support and Data Entry Pace}

During assessment a research assistant was present to offer support to patients if required and to record the time of data entry. Additionally, the support with completing the data entry was rated by the research assistant by means of a four-point Likert scale: 1, no support: patient enters data independently; 2, little required support: patient needs few instructions before 
medRxiv preprint doi: https://doi.org/10.1101/2021.10.01.21264398; this version posted October 1, 2021. The copyright holder for this preprint (which was not certified by peer review) is the author/funder, who has granted medRxiv a license to display the preprint in All rights reserved. No reuse allowed without permission.

entering data; 3, some required support: patient needs instructions several times; 4, a lot of support: for the most part the patient is dependent on help. The average support and the mean time for data entry (in minutes) at baseline were assessed.

To assess the relation between age, gender, level of functioning, depressive and psychotic symptoms and required support of PSSDs we estimated an ordinal logistic regression model. Age, gender, baseline sum scores of HAMD, GAF, PANSS and general psychopathology sub score of the PANSS represented the independent variables while support was defined as the dependent variable.

Similarly, we assessed the relation between age, gender, HAMD, GAF and PANSS with data entry pace of PSSDs. The independent variables consisted of age, gender, the baseline sum scores of HAMD, GAF and PANSS and the general psychopathology scale of the PANSS. Data entry pace served as the dependent variable.

\section{Statistical analyses}

Statistics were computed using the SPSS software package (version 26; IBM Corp). We aimed to explore the patients' acceptance, the performance and the required time to carry out the digital data assessment and had a special interest in the differences between PSSDs and PADs. In order to compare the subjective experience, the required support and data entry pace in the two patient groups we used two-tailed sample t-tests and chi-square tests. We followed the same procedure when comparing the age and gender of participants and nonparticipants. As the data on symptom severity was not available for nonparticipants we could not assess differences in these measures.

Regression analyses were performed in order to identify variables that were significantly associated with the subjective experience, support and data entry pace of PSSDs. 
medRxiv preprint doi: https://doi.org/10.1101/2021.10.01.21264398; this version posted October 1, 2021. The copyright holder for this preprint (which was not certified by peer review) is the author/funder, who has granted medRxiv a license to display the preprint in All rights reserved. No reuse allowed without permission.

For all models, uncorrected $P$ values as well as Benjamini-Hochberg false discovery ratecorrected $P$ values are reported.

\section{Results}

\section{Demographics}

100 patients participated in the study of whom 49 (49\%) were diagnosed with a schizophrenia spectrum disorder and $51(51 \%)$ with an affective disorder.

Out of 82 approached PSSDs 49 (59.8\%) agreed to participate in the study, while 33 (40.2\%) patients did not meet inclusion criteria or refused participation (Figure 1). 51 (51\%) PADs participated in the study during the outlined recruitment period, $49(49 \%)$ either could not be included or refused participating (Figure 2).

We found no statistically significant differences neither in the participation $\left(\mathrm{X}^{2}=1.395\right.$, $\mathrm{P}=.237)$ nor the refusal rate $\left(\mathrm{X}^{2}=.045, \mathrm{P}=.832\right)$ between both patient groups.

Figure 1. Study flow chart: Patients with a schizophrenia spectrum disorder (PSSDs)

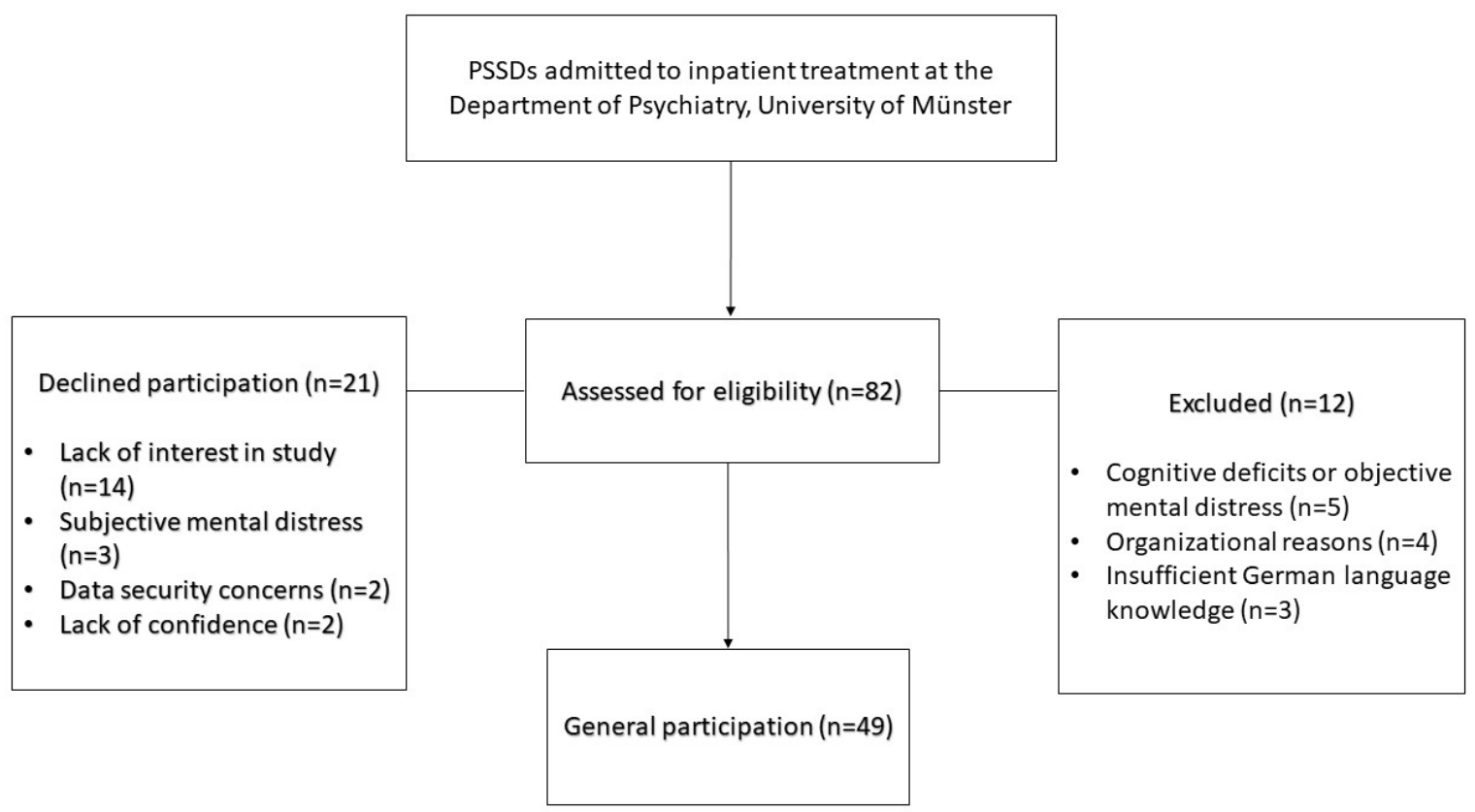


medRxiv preprint doi: https://doi.org/10.1101/2021.10.01.21264398; this version posted October 1, 2021. The copyright holder for this preprint (which was not certified by peer review) is the author/funder, who has granted medRxiv a license to display the preprint in

All rights reserved. No reuse allowed without permission.

Figure 2. Study flow chart: Patients with an affective disorder (PADs)

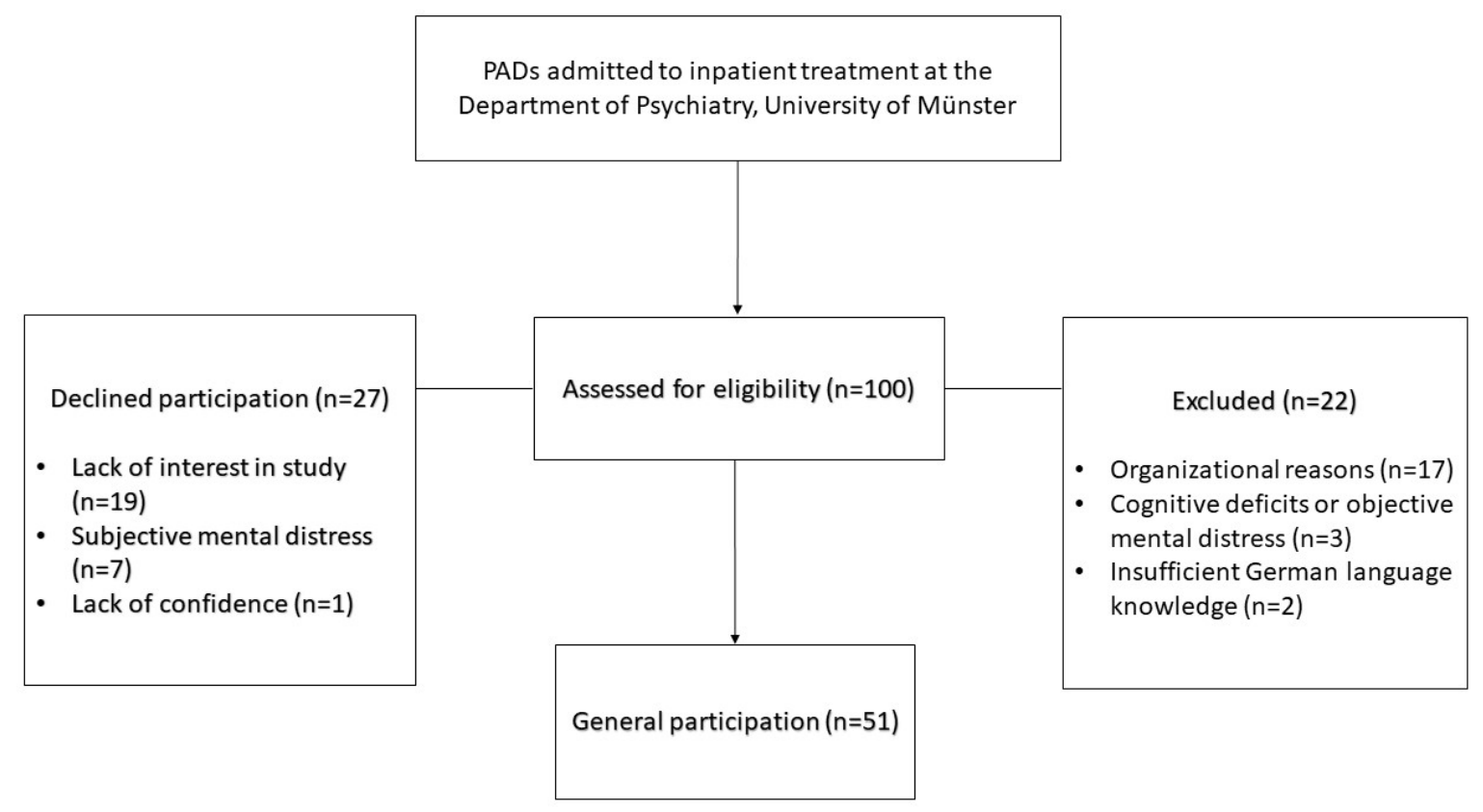

Mean duration of hospitalization of PSSDs was 56.39 ( $\mathrm{SD}=37.48)$ days with on average 2.79 $(\mathrm{SD}=1.69)$ and a median of two assessments (range 1-7). Mean duration of hospitalization of PADs was $52.60(\mathrm{SD}=23.68)$ days with an average of $3.48(\mathrm{SD}=1.66)$ and a median of four assessments (range 1-8).

The two patient groups did not show significant differences in age $\left(\mathrm{t}_{98}=.366, \mathrm{P}=.715\right.$, $\left.\mathrm{P}_{\mathrm{FDR}}=.737.\right)$, duration of illness $\left(\mathrm{t}_{93}=-1.103, \mathrm{P}=.273, \mathrm{P}_{\mathrm{FDR}}=.387\right)$ and years of education $\left(\mathrm{X}^{2}=8.63, \mathrm{P}=.196, \mathrm{P}_{\mathrm{FDR}}=.340\right)$. Gender distribution differed between PSSDs and PADs with higher frequency of men in the SSD group (Table 2)

Table 2: Sociodemographic and clinical characteristics of PSSDs and PADs at baseline assessment

Variables

Schizophrenia

Affective

P value $P_{\text {FDR value }}$

spectrum disorder disorder

\section{Age (years)}

Mean (SD)

39.22 (13.76)

38.20 (14.28)

.715

.737 
medRxiv preprint doi: https://doi.org/10.1101/2021.10.01.21264398; this version posted October 1 , 2021. The copyright holder for this preprint (which was not certified by peer review) is the author/funder, who has granted medRxiv a license to display the preprint in All rights reserved. No reuse allowed without permission.
Range
$19-72$
19-70

\section{Gender (n)}

Male

.099

Female

17

28

\section{Age of first psychiatric contact}

Mean (SD)

Range

BDI

Mean (SD)

Range

HAMD

Mean (SD)

Range

\section{GAF}

Mean (SD)

Range

SES

Mean (SD)

Range

PANSS Composite

Mean (SD)

Range

$66-111(n=46)$
$12.34(5.12)$

$1-24(\mathrm{n}=47)$

$15.83(5.94)$

$.003^{* *}$

$.017^{*}$

$48.64(7.17)$

$30-65(n=47)$

$27.51(10.62)$ .273 .387

$6-58(n=49)$

$25.19(11.61)$

$<.001^{* * *}<.001^{* * *}$

$7-49(\mathrm{n}=48)$

$3-25(n=48)$

$52.19(7.38)$

$.020^{*}$

.063

$41-79(n=47)$

$$
26.30(6.77)
$$

$22.68(6.47)$

$.010^{*} \quad .045^{*}$

$10-40(\mathrm{n}=47)$

$11-40(\mathrm{n}=50)$

\section{PANSS Positive}

$\begin{array}{llr}\text { Mean (SD) } & 21.57(4,37) & \text { N/A } \\ \text { Range } & 11-29(\mathrm{n}=46) & \text { N/A }\end{array}$


medRxiv preprint doi: https://doi.org/10.1101/2021.10.01.21264398; this version posted October 1 , 2021. The copyright holder for this preprint (which was not certified by peer review) is the author/funder, who has granted medRxiv a license to display the preprint in

All rights reserved. No reuse allowed without permission.

\section{PANSS Negative}

$\begin{array}{lll}\text { Mean (SD) } & 21.09(4.64) & \text { N/A } \\ \text { Range } & 13-34(n=46) & \text { N/A }\end{array}$

\section{PANSS General Psychopathology}

$\begin{array}{llr}\text { Mean (SD) } & 45.13(5.88) & \text { N/A } \\ \text { Range } & 34-61(n=46) & \text { N/A }\end{array}$

* Significant difference between patient groups using independent sample t-test

$\uparrow$ Significant difference between patient groups using chi-square test

Note: $* \mathrm{P}<.05, * * \mathrm{P}<.01, * * * \mathrm{P}<.001 ; \uparrow \mathrm{P}<.05, \uparrow \uparrow \mathrm{P}<.01, \uparrow \uparrow \uparrow \mathrm{P}<.001$

Duration of illness was defined by the year of first contact with a mental health care professional

$\mathrm{N} / \mathrm{A}=$ not applicable

${ }^{a}$ Benjamini-Hochberg false discovery rate-corrected $P$ value.

Missing answers were most often found in the BDI (10 patients (10\%) with SSD or AD skipped at least one question).

One patient of each patient group quit the baseline assessment due to concentration problems.

The nonparticipating group of PSSDs consisted of more women than the participating group. However, false discovery rate corrected p-values indicated no statistically significant association between gender and participation $\left(\mathrm{n}=82, \mathrm{X}^{2}=5.38, \mathrm{P}=.21, \mathrm{P}_{\mathrm{FDR}}=.063\right)$. The nonparticipating group of PADs was older than patients of the participating group ( $\mathrm{t}(98)$ $\left.=3.51, \mathrm{P}=.001, \mathrm{P}_{\mathrm{FDR}}=.011\right)$. There was no difference in age between the participating and nonparticipating group of PSSDs $\left(\mathrm{t}(80)=1.06, \mathrm{P}=.291, \mathrm{P}_{\mathrm{FDR}}=.387\right)$. Please refer to Table $\mathrm{S} 7$ for more information on Nonparticipants.

\section{Acceptance}

The assessment was positively received by both subsamples; $98 \%$ of patients in both groups were either satisfied or very satisfied with the data entry (Table 1, question 9). The individual 
medRxiv preprint doi: https://doi.org/10.1101/2021.10.01.21264398; this version posted October 1, 2021. The copyright holder for this preprint (which was not certified by peer review) is the author/funder, who has granted medRxiv a license to display the preprint in All rights reserved. No reuse allowed without permission.

Tablet-experience score indicating the patient's subjective confidence and security during data entry did not differ significantly between the two diagnosis groups $(\mathrm{t}(95)=-.880, \mathrm{p}=.381$, $\mathrm{P}_{\mathrm{FDR}}=.449$; Table 3 ). $72 \%$ of PSSDs and $62 \%$ of PADs could imagine integrating an eHealth app into their daily life (Table 1, question 10). We found, that higher Tablet-experience score values correlated with less required support by patients $(\mathrm{r}(95)=-.498, \mathrm{p}<.001)$ and a faster data entry pace $(\mathrm{r}(95)=-.430, \mathrm{p}<.001$; Table $\mathrm{S} 3)$.

Table 3: Group comparison on the Tablet-experience score

\begin{tabular}{|c|c|c|c|c|}
\hline Variable & Schizophrenia & Affective & $\mathrm{P}$ value & $P_{\text {FDR value }}{ }^{a}$ \\
\hline
\end{tabular}

\section{Tablet-experience score}

$\begin{array}{lllll}\text { Mean } & 16.87 & 17.32 & .381 & .449 \\ \text { Range } & 12-20(\mathrm{n}=47) & 11-20(\mathrm{n}=50) & & \end{array}$

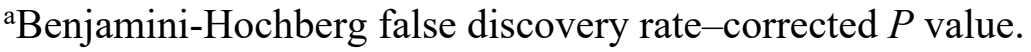

The variables used in our regressions showed a significant Pearson correlation in a preperformed correlation matrix (Table S3).

Predictor variables for the Tablet-experience score were tested by means of a linear regression model. We checked for multicollinearity of the independent variables using the tolerance and the variance inflation factor (VIF). Results indicated that multicollinearity was not a concern (Age, Tolerance $=.847, \mathrm{VIF}=1.180 ;$ Gender, Tolerance $=.923, \mathrm{VIF}=1.084 ;$ HAMD, Tolerance $=.494, \mathrm{VIF}=2.023 ; \mathrm{GAF}$, Tolerance $=.827, \mathrm{VIF}=1.210 ; \mathrm{SES}$, Tolerance $=.599$, $\mathrm{VIF}=1.668)$. The model was significant and explained $45.7 \%$ of the variance in the Tabletexperience score $\left(\mathrm{R}^{2}=.457, \mathrm{~F}=6.238, \mathrm{P}<.001\right)$. Age, gender, HAMD, GAF and SES served as independent variables whereas the Tablet-experience score served as the dependent variable. Age and HAMD were found to be statistically significant negative predictors of the model (Table S4). However, associations did not uphold when correcting for multiple comparisons. 
medRxiv preprint doi: https://doi.org/10.1101/2021.10.01.21264398; this version posted October 1, 2021. The copyright holder for this preprint (which was not certified by peer review) is the author/funder, who has granted medRxiv a license to display the preprint in All rights reserved. No reuse allowed without permission.

\section{Support and data entry pace}

Approximately half of PSSDs (26/54.2\%) and the majority of PADs (41/82\%) could enter data without any support (Figure 3). PSSDs needed significantly more support compared to PADs $\left(\mathrm{X}^{2}=11.21, \mathrm{P}=.011, \mathrm{P}_{\mathrm{FDR}}=.045 ;\right.$ Table 4$)$.

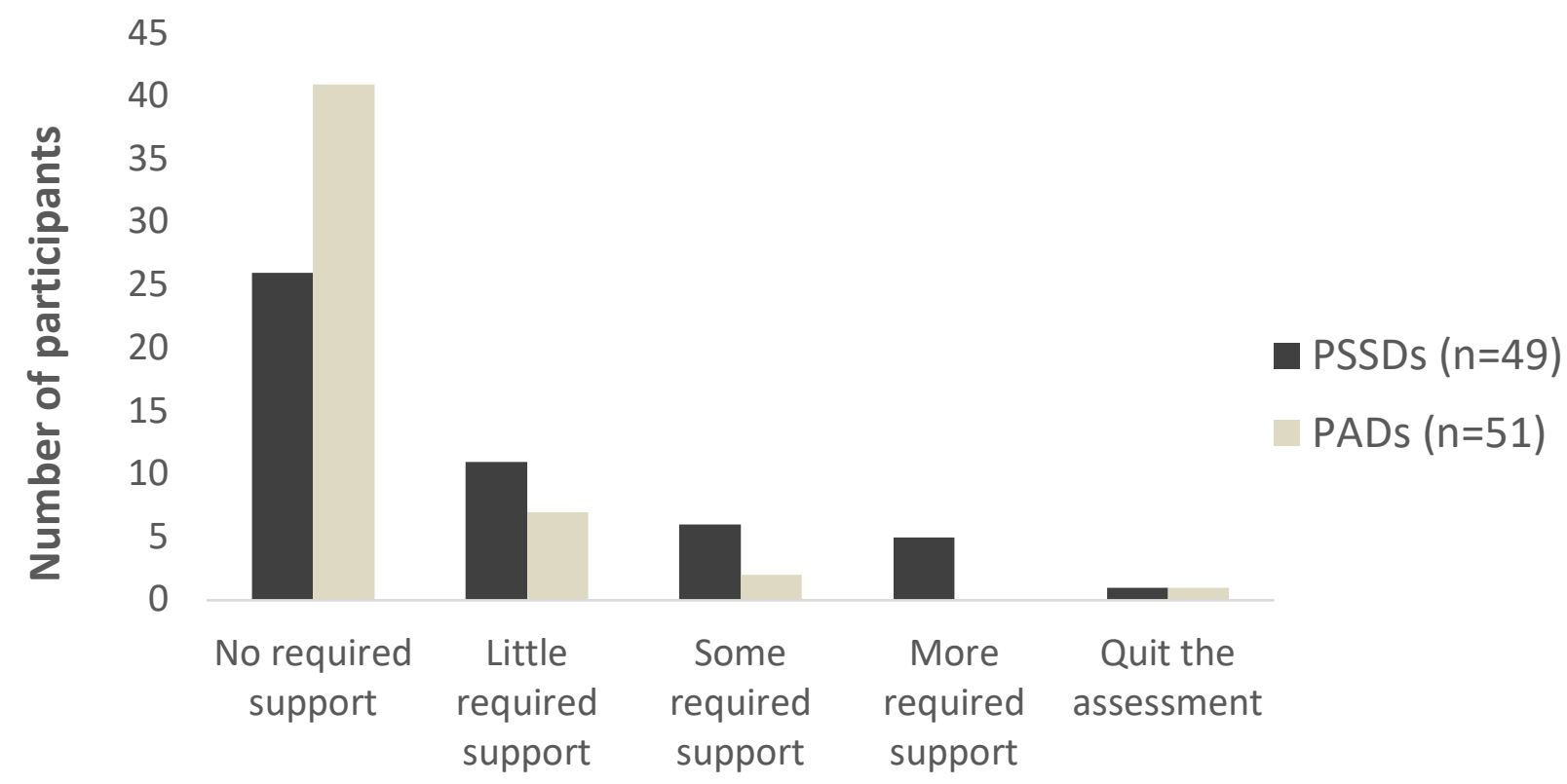

Figure 3: Required support during data entry $(n=100)$

PSSDs needed on average 53.1 minutes $(\mathrm{SD}=22.94)$ to complete the assessment at baseline while PADs needed 38.56 minutes. There was a statistically significant difference in time $\left(\mathrm{t}(96)=3.86, \mathrm{P}<.001, \mathrm{P}_{\mathrm{FDR}}<.001 ;\right.$ Table 4$)$.

Table 4: Group comparisons on required support and data entry pace during data entry

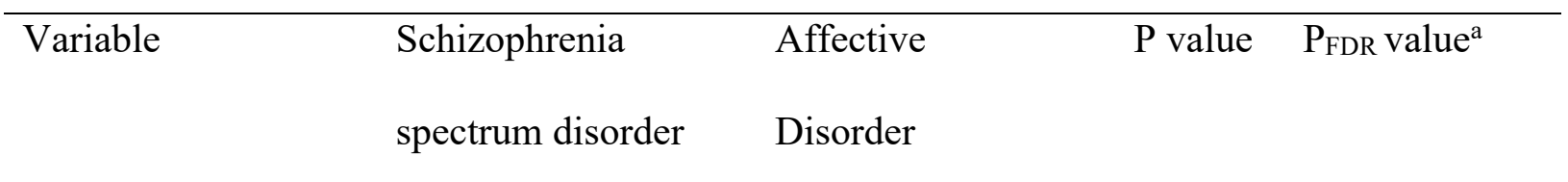

\section{Required support}

Mean

$0.79^{\mathrm{b}}$

$0.22^{\mathrm{b}}$

$.011^{\uparrow}$

$.045^{*}$

Range

$0-3^{b}(n=48)$

$0-2^{b}(n=50)$ 
medRxiv preprint doi: https://doi.org/10.1101/2021.10.01.21264398; this version posted October 1, 2021. The copyright holder for this preprint (which was not certified by peer review) is the author/funder, who has granted medRxiv a license to display the preprint in All rights reserved. No reuse allowed without permission.

\section{Data entry pace (in minutes)}

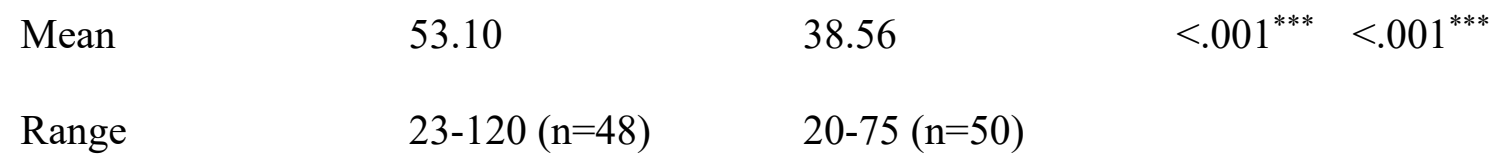

* Significant difference between patient groups using independent-sample t-test

$\uparrow$ Significant difference between patient groups using chi-square test

Note: $* \mathrm{P}<.05, * * \mathrm{P}<.01, * * * \mathrm{P}<.001 ; \uparrow \mathrm{P}<.05, \uparrow \uparrow \mathrm{P}<.01, \uparrow \uparrow \uparrow \mathrm{P}<.001$

aBenjamini-Hochberg false discovery rate-corrected $P$ value.

bLikert scale: 0, no support; 1, Little support; 2, some support; 3, a lot of support

Predictors for required support of PSSDs were tested by means of an ordinal logistic regression model. The model fit of the regression was given, $\mathrm{X}^{2}=28.930, \mathrm{P}=<.001$. According to Nagelkerke $R^{2}$, the model explained $53.2 \%$ of the variance. Age, gender, HAMD, GAF, PANSS composite and PANSS general psychopathology served as independent variables and the level of required support as the dependent variable. Age was found to be the only significant predictor of required support. The odds of needing assistance for the data entry increased with age (odds ratio [OR] 1.10, 95\% CI 1.03-1.17; $\mathrm{P}=.003, \mathrm{P}_{\mathrm{FDR}}=.017$; Table S5).

The linear regression model for the data entry pace of PSSDs was significant and explained $36.9 \%$ of the variance in data entry time (adjusted $\mathrm{R}^{2}=.369, \mathrm{~F}=5.001, \mathrm{P}=.001$ ). The tolerance and VIF indicated that multicollinearity was not a concern $($ Age, Tolerance $=.81, \mathrm{VIF}=1.23$; Gender, Tolerance $=.76, \mathrm{VIF}=1.33 ;$ HAMD, Tolerance $=.53, \mathrm{VIF}=1.89 ;$ PANSS, Tolerance $=$ $.17, \mathrm{VIF}=5.82$; General symptom psychopathology scale, Tolerance $=.17, \mathrm{VIF}=5.78 ; \mathrm{SES}$; Tolerance $=.61, \mathrm{VIF}=1.65)$. Age, gender, HAMD, PANSS composite, PANSS general psychopathology and the SES were the independent variables and the time in minutes for data entry the dependent variable. The SES, the PANSS and the age of patients contributed significantly to the model. The SES was found to be a statistically negative predictor, whereas 
medRxiv preprint doi: https://doi.org/10.1101/2021.10.01.21264398; this version posted October 1 , 2021. The copyright holder for this preprint (which was not certified by peer review) is the author/funder, who has granted medRxiv a license to display the preprint in All rights reserved. No reuse allowed without permission.

the PANSS and age contributed positively to the model (Table S6). The associations of the PANSS and age did not uphold when testing for multiple comparisons.

\section{Discussion}

We investigated the acceptance and feasibility of a digital data collection routine during inpatient psychiatric treatment based on self-reports in PSSDs in direct comparison to PADs. Our main findings indicate that PSSDs were equally motivated and willing to engage in digital data collection compared to PADs but needed more support and time for the completion of digital assessments.

While previous studies already showed the feasibility of digital data assessments in outpatient treatment of PSSDs (Liu et al., 2019; Tolley et al., 2015) this study is, to our knowledge, the first demonstrating the acceptance and feasibility of this approach in inpatients in a naturalistic clinical environment. Of all patients who met the inclusion criteria $59.8 \%$ of PSSDs and $51 \%$ of PADs agreed to participate in this study. These percentages are comparable to studies in the general population (Grobbee et al., 2005) or in non-psychiatric cardiovascular patients (Asselbergs et al., 2017). The diagnosis of a disorder in the spectrum of schizophrenia does not seem to negatively affect the participation rate in a digital data collection effort in clinical routine.

Gathering digital data was assumed to aggravate paranoid ideas in PSSDs, increasing fears of having questionnaire responses tracked and used against them (Chivilgina et al., 2021; Lal et al., 2020). Both PSSDs and PADs showed similar participation rates and gave similar reasons if they refused to participate, which indicates that paranoid ideas did not constitute an obstacle to participate in digitally based data collections, at least in our sample. Only two patients refused to participate because of explicit data security concerns. Few patients declined participation or were excluded by clinicians due to cognitive deficits or symptom severity before being approached. The most common reason for nonparticipation was a general 
medRxiv preprint doi: https://doi.org/10.1101/2021.10.01.21264398; this version posted October 1 , 2021. The copyright holder for this preprint (which was not certified by peer review) is the author/funder, who has granted medRxiv a license to display the preprint in All rights reserved. No reuse allowed without permission.

disinterest in the study, which is also one of the main factors for non-use of digital-reported outcome concepts in non-psychiatric patients (Nielsen et al., 2020).

PSSDs were as confident during data entry as PADs and had the impression they could understand and answer questionnaires equally well. This is a very promising result, as previous investigations have demonstrated that PSSDs, in particular older patients, lack confidence in using a computer or a smartphone (Too et al., 2020; Wong et al., 2020). It should be considered that we asked for the patients' self-evaluation after they entered data with the tablet. It is possible that the patients would have had lower confidence with digital devices if they had been asked before the assessment, as the first assessment could have had a positive effect on their confidence already. Previous data supports that hypothesis and suggests that the use of technology itself leads to self-esteem enhancement (Pourrazavi et al., 2020; Vaportzis et al., 2018). Age had indeed a negative effect on the Tablet-experience score. Even if this trend was not upheld when testing for multiple comparisons, this finding draws attention to not just a psychiatric but societal problem: older adults are still less likely to develop the confidence to engage with digital media and the internet (Gordon \& Hornbrook, 2018; Mannheim et al., 2019).

Thirty-eight percent of PSSDs had never used a tablet before being approached for the study and still $98 \%$ were either satisfied or very satisfied with the assessment after data entry. Furthermore $72 \%$ of patients were open towards installing an eHealth application on their smartphone compared to $62 \%$ of PADs, which goes hand in hand with previous studies stating that PSSDs want to get more in touch with digital tools (Ben-Zeev et al., 2018).

Despite the comparatively high participation rate and the overall satisfaction with the assessment, PSSDs had a lower adherence rate than PADs, which can be seen in the mean and median of conducted assessments. When being asked to give an update on their symptom severity every other week fewer PSSDs than PADs were willing to do so. Previous studies 
medRxiv preprint doi: https://doi.org/10.1101/2021.10.01.21264398; this version posted October 1 , 2021. The copyright holder for this preprint (which was not certified by peer review) is the author/funder, who has granted medRxiv a license to display the preprint in All rights reserved. No reuse allowed without permission.

have already witnessed lower rates of adherence in new technology based interventions with PSSDs (Alvarez-Jimenez et al., 2014). Killikelly (2017) found male gender and younger age to be specific predictors of nonadherence in mobile and web-based interventions which comprises a big part of the participants with a schizophrenia spectrum disorder in our study. Future studies should keep this in mind and adjust the frequency of assessments to the capabilities and demands of patients.

Regarding the required support, more than half of the PSSDs could read and answer the tablet-based questionnaires independently. Only four patients required a lot of support and relied on the research assistant for the assessment. Overall, PSSDs needed more support and more time for data entry compared to PADs. However, only one patient quit the assessment due to concentration problems and did not finish the data entry at baseline. In conclusion, the diagnosis of a disorder in the schizophrenic spectrum does not seem to have an effect on the dropout rate, a patient might just need to be presented more assistance and patience while handling a digital device. We found the required support to be associated with patients' age which is in line with studies on general non-clinical samples (Wildenbos et al., 2019) and PADs (Richter et al., 2020). As older adults in general are not as experienced in the use of digital devices this result does not come as a surprise (Mitzner et al., 2019).

The feeling of self-efficacy showed a negative association with the data entry pace of PSSDs. Studies have already shown that low self-efficacy reduces the ability of using a tablet device in older adults (Alvseike \& Brønnick, 2012), whereas higher self-efficacy seems to lead to a decrease in computer anxiety (Pourrazavi et al., 2020). There are strategies for increasing the feeling of self-efficacy (Bryce et al., 2018). Clinicians should put a focus on strengthening the patients' feeling of self-efficacy in order to successfully introduce digital data efforts.

There was a trend for symptom severity (PANSS) to be positively related to the degree of required support. Although this trend was not upheld when testing for multiple comparisons 
medRxiv preprint doi: https://doi.org/10.1101/2021.10.01.21264398; this version posted October 1 , 2021. The copyright holder for this preprint (which was not certified by peer review) is the author/funder, who has granted medRxiv a license to display the preprint in All rights reserved. No reuse allowed without permission.

the result is worth discussing. As the PANSS contains aspects like conceptual disorganization, difficulty in abstract thinking, disorientation and poor attention (Kay et al., 1987) it is plausible that the score is associated with the tablet handling performance. However, a greater severity of symptoms was not associated with a higher dropout rate.

While investigation of the validity of patients' self-reports was not the primary aim of the present study, the strong correlation between the BDI and the HAMD indicated a high validity of patient-reported outcomes. The level of agreement was comparable to what is suggested in the literature (Steer et al., 1987). This is a promising result for the implementation of longitudinal digital data collection for the clinical daily routine and research efforts, as it suggests that no additional clinical personnel is required to gain valid information from PSSDs.

There are limitations to this study. We used the baseline sum scores of BDI, HAMD and SES for our calculations. They could only be applied if all aspects of the questionnaire were answered. Patients were asked to answer all the questions, however they had the opportunity to skip questions. If one question of the instruments above was not answered the total sum score could not be evaluated. We did not assess whether patients skipped questions because they did not understand their meaning or because they did not feel comfortable answering them. However, the great majority of patients answered all questions. The validity of selfassessments was only tested for depression questionnaires. Subsequent studies should also look at the validity of scores that explore the symptoms of a schizophrenia spectrum disorder. Moreover, it should be addressed that our sample size is not big enough to represent the whole clinical population that suffers from schizophrenia spectrum disorders. As this study is one of the first of its kind the sample size is too small to make representative statements. Therefore, future studies should be based on more representative cohorts. 
medRxiv preprint doi: https://doi.org/10.1101/2021.10.01.21264398; this version posted October 1, 2021. The copyright holder for this preprint (which was not certified by peer review) is the author/funder, who has granted medRxiv a license to display the preprint in All rights reserved. No reuse allowed without permission.

This study explored the feasibility of an implementation of a digital data collection through inpatient treatment of patients suffering from a schizophrenia spectrum disorder in a naturalistic clinical environment. To sum up, while PSSDs needed more support and time for the completion of digital assessments, they were equally open towards them and willing to engage in such efforts compared to PADs. Our findings suggest that digitally assessed selfreport measures are well-received in PSSDs and PADs alike and that patients are willing to enter data and give feedback on their symptom severity. As PSSDs were as open towards these technological approaches and showed great confidence while using digital devices, they should be further integrated in digital research efforts. The present results should urge future clinical and research efforts to include PSSDs in digital assessment routines but to account for the higher level of required time and support during digital assessments in PSSDs e.g. by offering personal assistance and ensuring adequate setting during assessments. Achieving these steps could reduce the digital exclusion of PSSDs and hence challenge prevailing stigmas related to SSDs. 
medRxiv preprint doi: https://doi.org/10.1101/2021.10.01.21264398; this version posted October 1 , 2021. The copyright holder for this preprint (which was not certified by peer review) is the author/funder, who has granted medRxiv a license to display the preprint in All rights reserved. No reuse allowed without permission.

\section{Abbreviations}

$\mathrm{AD}$

Affective disorder

BDI

Beck's Depression Inventory

BFI

Big Five Inventory

CTQ

Childhood Trauma Questionnaire

GAF

Global Assessment of Functioning

HAMD Hamilton Depression Scale

PADs Patients with an affective disorder

PANSS Positive and Negative Symptom Scale

PSSDs Patients with a schizophrenia spectrum disorder

SES Self-Efficacy Scale

SSD Schizophrenia spectrum disorder 
medRxiv preprint doi: https://doi.org/10.1101/2021.10.01.21264398; this version posted October 1 , 2021. The copyright holder for this preprint (which was not certified by peer review) is the author/funder, who has granted medRxiv a license to display the preprint in All rights reserved. No reuse allowed without permission.

\section{Acknowledgements}

We are deeply indebted to all participants of this study. Funding was provided by the Interdisciplinary Center for Clinical Research (IZKF) of the medical faculty of Münster (Grant SEED 11/19 to NO), as well as the "Innovative Medizinische Forschung" (IMF) of the medical faculty of Münster (Grants OP121710 to NO). The study was further supported by a grant from BMBF (HiGHmed 01ZZ1802V).

\section{References}

Ahmed, A. O., Strauss, G. P., Buchanan, R. W., Kirkpatrick, B., \& Carpenter, W. T. (2018).

Schizophrenia heterogeneity revisited: Clinical, cognitive, and psychosocial correlates of statistically-derived negative symptoms subgroups. Journal of Psychiatric Research, 97, 8-15. https://doi.org/10.1016/j.jpsychires.2017.11.004

Alfonsson, S., Maathz, P., \& Hursti, T. (2014). Interformat reliability of digital psychiatric self-report questionnaires: A systematic review. Journal of Medical Internet Research, 16(12). https://doi.org/10.2196/jmir.3395

Alvarez-Jimenez, M., Alcazar-Corcoles, M. A., González-Blanch, C., Bendall, S., McGorry, P. D., \& Gleeson, J. F. (2014). Online, social media and mobile technologies for psychosis treatment: A systematic review on novel user-led interventions. Schizophrenia Research, 156(1), 96-106. https://doi.org/10.1016/j.schres.2014.03.021

Alvarez-Jimenez, M., Priede, A., Hetrick, S. E., Bendall, S., Killackey, E., Parker, A. G., McGorry, P. D., \& Gleeson, J. F. (2012). Risk factors for relapse following treatment for first episode psychosis: A systematic review and meta-analysis of longitudinal studies. Schizophrenia Research, 139(1-3), 116-128.

https://doi.org/10.1016/j.schres.2012.05.007

Alvseike, H., \& Brønnick, K. (2012). Feasibility of the iPad as a hub for smart house technology in the elderly; effects of cognition, self-efficacy, and technology experience. Journal of Multidisciplinary Healthcare, 5, 299-306. 
medRxiv preprint doi: https://doi.org/10.1101/2021.10.01.21264398; this version posted October 1 , 2021. The copyright holder for this preprint (which was not certified by peer review) is the author/funder, who has granted medRxiv a license to display the preprint in All rights reserved. No reuse allowed without permission.

https://doi.org/10.2147/JMDH.S35344

Aref-Adib, G., Landy, G., Eskinazi, M., Sommerlad, A., Morant, N., Johnson, S., Graham, R., Osborn, D., \& Pitman, A. (2020). Assessing digital risk in psychiatric patients: Mixed methods study of psychiatry trainees' experiences, views, and understanding. JMIR Mental Health, 7(7), 1-13. https://doi.org/10.2196/19008

Asselbergs, F. W., Visseren, F. L. J., Bots, M. L., De Borst, G. J., Buijsrogge, M. P., Dieleman, J. M., Van Dinther, B. G. F., Doevendans, P. A., Hoefer, I. E., Hollander, M., De Jong, P. A., Koenen, S. V., Pasterkamp, G., Ruigrok, Y. M., Van Der Schouw, Y. T., Verhaar, M. C., \& Grobbee, D. E. (2017). Uniform data collection in routine clinical practice in cardiovascular patients for optimal care, quality control and research: The Utrecht Cardiovascular Cohort. European Journal of Preventive Cardiology, 24(8), 840847. https://doi.org/10.1177/2047487317690284

Barnett, I., Torous, J., Staples, P., Sandoval, L., Keshavan, M., \& Onnela, J. P. (2018).

Relapse prediction in schizophrenia through digital phenotyping: A pilot study. Neuropsychopharmacology, 43(8), 1660-1666. https://doi.org/10.1038/s41386-018$0030-\mathrm{z}$

Beck, A. T., Ward, C. H., Mendelson, M., Mock, J., \& Erbaugh, J. (1960). An Inventory for Measuring Depression The difficulties inherent in obtaining. 561-571. doi: 10.1001/archpsyc.1961.01710120031004. PMID: 13688369.

Ben-Zeev, D., Brian, R. M., Jonathan, G., Razzano, L., Pashka, N., Carpenter-Song, E., Drake, R. E., \& Scherer, E. A. (2018). Mobile health (mHealth) versus clinic-based group intervention for people with serious mental illness: A randomized controlled trial. Psychiatric Services, 69(9), 978-985. https://doi.org/10.1176/appi.ps.201800063

Ben-Zeev, D., Davis, K. E., Kaiser, S., Krzsos, I., \& Drake, R. E. (2013). Mobile technologies among people with serious mental illness: Opportunities for future services. Administration and Policy in Mental Health and Mental Health Services Research, 
medRxiv preprint doi: https://doi.org/10.1101/2021.10.01.21264398; this version posted October 1 , 2021. The copyright holder for this preprint (which was not certified by peer review) is the author/funder, who has granted medRxiv a license to display the preprint in All rights reserved. No reuse allowed without permission.

40(4), 340-343. https://doi.org/10.1007/s10488-012-0424-x

Ben-Zeev, D., Scherer, E. A., Gottlieb, J. D., Rotondi, A. J., Brunette, M. F., Achtyes, E. D., Mueser, K. T., Gingerich, S., Brenner, C. J., Begale, M., Mohr, D. C., Schooler, N., Marcy, P., Robinson, D. G., \& Kane, J. M. (2016). mHealth for Schizophrenia: Patient Engagement With a Mobile Phone Intervention Following Hospital Discharge. JMIR Mental Health, 3(3), e34. https://doi.org/10.2196/mental.6348

Bernstein, D. P., Ahluvalia, T., Pogge, D., \& Handelsman, L. (1997). Validity of the childhood trauma questionnaire in an adolescent psychiatric population. Journal of the American Academy of Child and Adolescent Psychiatry, 36(3), 340-348. https://doi.org/10.1097/00004583-199703000-00012

Berry, N., Emsley, R., Lobban, F., \& Bucci, S. (2018). Social media and its relationship with mood, self-esteem and paranoia in psychosis. Acta Psychiatrica Scandinavica, 138(6), 558-570. https://doi.org/10.1111/acps.12953

Berry, Natalie, Lobban, F., \& Bucci, S. (2019). A qualitative exploration of service user views about using digital health interventions for self-management in severe mental health problems. BMC Psychiatry, 19(1), 1-13. https://doi.org/10.1186/s12888-018-1979-1

Blitz, R., Storck, M., Baune, B. T., Dugas, M., \& Opel, N. (2021). Design and implementation of an informatics infrastructure for standardized data acquisition, transfer, storage, and export in psychiatric clinical routine: Feasibility study. JMIR Mental Health, 8(6). https://doi.org/10.2196/26681

Bryce, S. D., Rossell, S. L., Lee, S. J., Lawrence, R. J., Tan, E. J., Carruthers, S. P., \& Ponsford, J. L. (2018). Neurocognitive and self-efficacy benefits of cognitive remediation in schizophrenia: A randomized controlled trial. Journal of the International Neuropsychological Society, 24(6), 549-562. https://doi.org/10.1017/S1355617717001369

Bucci, S., Morris, R., Berry, K., Berry, N., Haddock, G., Barrowclough, C., Lewis, S., \& 
medRxiv preprint doi: https://doi.org/10.1101/2021.10.01.21264398; this version posted October 1, 2021. The copyright holder for this preprint (which was not certified by peer review) is the author/funder, who has granted medRxiv a license to display the preprint in All rights reserved. No reuse allowed without permission.

Edge, D. (2018). Early Psychosis Service User Views on Digital Technology: Qualitative Analysis. JMIR Mental Health, 5(4), e10091. https://doi.org/10.2196/10091

Buchanan RW, C. W. (1994). domains of psychopathology.pdf. The Journal of Nervous and Mental Disease: April 1994 - Volume 182 - Issue 4 - p 193-204.

https://doi.org/10.1097/00005053-199404000-00001

Chivilgina, O., Elger, B. S., \& Jotterand, F. (2021). Digital Technologies for Schizophrenia Management: A Descriptive Review. Science and Engineering Ethics, 27(2), 1-22. https://doi.org/10.1007/s11948-021-00302-z

Daker-White, G., \& Rogers, A. (2013). What is the potential for social networks and support to enhance future telehealth interventions for people with a diagnosis of schizophrenia: A critical interpretive synthesis. BMC Psychiatry, 13(1), 1. https://doi.org/10.1186/1471244X-13-279

Ennis, L., Rose, D., Denis, M., Pandit, N., \& Wykes, T. (2012). Can’t surf, won’t surf: The digital divide in mental health. Journal of Mental Health, 21(4), 395-403. https://doi.org/10.3109/09638237.2012.689437

Firth \& Torous. (2015). Smartphone Apps for Schizophrenia: A Systematic Review. JMIR mHealth and uHealth, 3(4), e102. https://doi.org/10.2196/mhealth.4930

Fritz, F., Balhorn, S., Riek, M., Breil, B., \& Dugas, M. (2012). Qualitative and quantitative evaluation of EHR-integrated mobile patient questionnaires regarding usability and costefficiency. International Journal of Medical Informatics, 81(5), 303-313. https://doi.org/10.1016/j.ijmedinf.2011.12.008

Gordon, N. P., \& Hornbrook, M. C. (2018). Older adults' readiness to engage with eHealth patient education and self-care resources: A cross-sectional survey. BMC Health Services Research, 18(1), 1-13. https://doi.org/10.1186/s12913-018-2986-0

Greer, B., Robotham, D., Simblett, S., Curtis, H., Griffiths, H., \& Wykes, T. (2019). Digital exclusion among mental health service users: Qualitative investigation. Journal of 
medRxiv preprint doi: https://doi.org/10.1101/2021.10.01.21264398; this version posted October 1 , 2021. The copyright holder for this preprint (which was not certified by peer review) is the author/funder, who has granted medRxiv a license to display the preprint in All rights reserved. No reuse allowed without permission.

Medical Internet Research, 21(1), 1-9. https://doi.org/10.2196/11696

Grobbee, D. E., Hoes, A. W., Verheij, T. J. M., Schrijvers, A. J. P., Van Ameijden, E. J. C., \& Numans, M. E. (2005). The Utrecht Health Project: Optimization of routine healthcare data for research. European Journal of Epidemiology, 20(3), 285-290. https://doi.org/10.1007/s10654-004-5689-2

Habtewold, T. D., Rodijk, L. H., Liemburg, E. J., Sidorenkov, G., Boezen, H. M., Bruggeman, R., \& Alizadeh, B. Z. (2020). A systematic review and narrative synthesis of data-driven studies in schizophrenia symptoms and cognitive deficits. Translational Psychiatry, 10(1). https://doi.org/10.1038/s41398-020-00919-x

Hall, R. C. W. (1995). Global Assessment of Functioning: A Modified Scale. Psychosomatics, 36(3), 267-275. https://doi.org/10.1016/S0033-3182(95)71666-8

Hamilton, M. (1960). Scale for depression. Matrix, 56-63. doi: 10.1136/jnnp.23.1.56. PMID: 14399272; PMCID: PMC495331

Henson, P., D’Mello, R., Vaidyam, A., Keshavan, M., \& Torous, J. (2021). Anomaly detection to predict relapse risk in schizophrenia. Translational Psychiatry, 11(1). https://doi.org/10.1038/s41398-020-01123-7

Hirschtritt, M. E., \& Insel, T. R. (2018). Digital Technologies in Psychiatry: Present and Future. Focus, 16(3), 251-258. https://doi.org/10.1176/appi.focus.20180001

Hsin, H., Fromer, M., Peterson, B., Walter, C., Fleck, M., Campbell, A., Varghese, P., \& Califf, R. (2018). Transforming Psychiatry into Data-Driven Medicine with Digital Measurement Tools. npj Digital Medicine, 1(1), 1-4. https://doi.org/10.1038/s41746018-0046-0

Humphreys, K. (2017). A review of the impact of exclusion criteria on the generalizability of schizophrenia treatme. Clinical Schizophrenia and Related Psychoses, 11(1), 49-57. https://doi.org/10.3371/1935-1232-11.1.49

Kahn, R. S., Sommer, I. E., Murray, R. M., Meyer-Lindenberg, A., Weinberger, D. R., 
medRxiv preprint doi: https://doi.org/10.1101/2021.10.01.21264398; this version posted October 1 , 2021. The copyright holder for this preprint (which was not certified by peer review) is the author/funder, who has granted medRxiv a license to display the preprint in All rights reserved. No reuse allowed without permission.

Cannon, T. D., O’Donovan, M., Correll, C. U., Kane, J. M., Van Os, J., \& Insel, T. R. (2015). Schizophrenia. Nature Reviews Disease Primers, 1(November). https://doi.org/10.1038/nrdp.2015.67

Kay, S. R., Fiszbein, A., \& Opler, L. A. (1987). The positive and negative syndrome scale (PANSS) for schizophrenia. Schizophrenia Bulletin, 13(2), 261-276. https://doi.org/10.1093/schbul/13.2.261

Kidd, S. A., Feldcamp, L., Adler, A., Kaleis, L., Wang, W., Vichnevetski, K., McKenzie, K., \& Voineskos, A. (2019). Feasibility and outcomes of a multi-function mobile health approach for the schizophrenia spectrum: APP4Independence (A4I). PLoS ONE, 14(7), 1-17. https://doi.org/10.1371/journal.pone.0219491

Killikelly, C., He, Z., Reeder, C., \& Wykes, T. (2017). Improving adherence to web-based and mobile technologies for people with psychosis: Systematic review of new potential predictors of adherence. JMIR mHealth and uHealth, 5(7). https://doi.org/10.2196/mhealth.7088

Kuzman, M. R., Andlauer, O., Burmeister, K., Dvoracek, B., Lencer, R., Koelkebeck, K., Nawka, A., \& Riese, F. (2017). The psylog mobile application: Development of a tool for the assessment and monitoring of side effects of psychotropic medication. Psychiatria Danubina, 29(2), 214-217. https://doi.org/10.24869/psyd.2017.214

Lal, S., Gleeson, J., Rivard, L., D’Alfonso, S., Joober, R., Malla, A., \& Alvarez-Jimenez, M. (2020). Adaptation of a digital health innovation to prevent relapse and support recovery in youth receiving services for first-episode psychosis: Results from the horyzons-canada phase 1 study. JMIR Formative Research, 4(10). https://doi.org/10.2196/19887

Liu, G., Henson, P., Keshavan, M., Pekka-Onnela, J., \& Torous, J. (2019). Assessing the potential of longitudinal smartphone based cognitive assessment in schizophrenia: A naturalistic pilot study. Schizophrenia Research: Cognition, 17(March), 100144. https://doi.org/10.1016/j.scog.2019.100144 
medRxiv preprint doi: https://doi.org/10.1101/2021.10.01.21264398; this version posted October 1 , 2021. The copyright holder for this preprint (which was not certified by peer review) is the author/funder, who has granted medRxiv a license to display the preprint in All rights reserved. No reuse allowed without permission.

Luszczynska, A., Scholz, U., \& Schwarzer, R. (2005). The general self-efficacy scale:

Multicultural validation studies. Journal of Psychology: Interdisciplinary and Applied, 139(5), 439-457. https://doi.org/10.3200/JRLP.139.5.439-457

Mannheim, I., Schwartz, E., Xi, W., Buttigieg, S. C., McDonnell-Naughton, M., Wouters, E. J. M., \& van Zaalen, Y. (2019). Inclusion of older adults in the research and design of digital technology. International Journal of Environmental Research and Public Health, 16(19), 1-17. https://doi.org/10.3390/ijerph16193718

Marcano Belisario, J. S., Huckvale, K., Saje, A., Porcnik, A., Morrison, C. P., \& Car, J. (2014). Comparison of self administered survey questionnaire responses collected using mobile apps versus other methods. Cochrane Database of Systematic Reviews, 2014(4). https://doi.org/10.1002/14651858.MR000042

McLaren, P., Summerfieldm, A. B., Watson, J. P., Lipsedge, M., \& Ball, C. J. (1995). An Evaluation of the Use of Interactive Television in an Acute Psychiatric Service. Journal of Telemedicine and Telecare, 1(2), 79-85. https://doi.org/10.1177/1357633X9500100203

Mehta, N., Pandit, A., \& Shukla, S. (2019). Transforming healthcare with big data analytics and artificial intelligence: A systematic mapping study. Journal of Biomedical Informatics, 100(November 2018), 103311. https://doi.org/10.1016/j.jbi.2019.103311

Mitzner, T. L., Savla, J., Boot, W. R., Sharit, J., Charness, N., Czaja, S. J., \& Rogers, W. A. (2019). Technology Adoption by Older Adults: Findings from the PRISM Trial. Gerontologist, 59(1), 34-44. https://doi.org/10.1093/geront/gny113

Monteith, S., Glenn, T., Geddes, J., Whybrow, P. C., \& Bauer, M. (2016). Big data for bipolar disorder. International Journal of Bipolar Disorders, 4(1).

https://doi.org/10.1186/s40345-016-0051-7

Mueser, K. T., \& Mcgurk, S. R. (2004). Schizophrenia. The Lancet Psychiatry Volume 363, Issue 9426, 19 June 2004, Pages 2063-2072, 363, 2063-2072. 
medRxiv preprint doi: https://doi.org/10.1101/2021.10.01.21264398; this version posted October 1 , 2021. The copyright holder for this preprint (which was not certified by peer review) is the author/funder, who has granted medRxiv a license to display the preprint in All rights reserved. No reuse allowed without permission.

https://doi.org/10.1016/S0140-6736(04)16458-1

Myin-Germeys, I. (2020). Digital technology in psychiatry: towards the implementation of a true person-centered care in psychiatry? European Archives of Psychiatry and Clinical Neuroscience, 270(4), 401-402. https://doi.org/10.1007/s00406-020-01130-1

Nielsen, A. S., Kidholm, K., \& Kayser, L. (2020). Patients' reasons for non-use of digital patient-reported outcome concepts: A scoping review. Health Informatics Journal, 26(4), 2811-2833. https://doi.org/10.1177/1460458220942649

Odendaal, W., J, A. W., Leon, N., Goudge, J., Gri, F., Tomlinson, M., Daniels, K., Wa, O., J, A. W., Leon, N., Goudge, J., Gri, F., Tomlinson, M., \& Daniels, K. (2020). evidence synthesis (Review).

https://doi.org/10.1002/14651858.CD011942.pub2.www.cochranelibrary.com

Pourrazavi, S., Kouzekanani, K., Bazargan-Hejazi, S., Shaghaghi, A., Hashemiparast, M., Fathifar, Z., \& Allahverdipour, H. (2020). Theory-based E-health literacy interventions in older adults: A systematic review. Archives of Public Health, 78(1), 1-8. https://doi.org/10.1186/s13690-020-00455-6

Preuschoff, I., Müller, H. H., Sperling, W., Biermann, T., Bergner, M., Kornhuber, J., \& Groemer, T. W. (2013). iPad-Assisted Measurements of Duration Estimation in Psychiatric Patients and Healthy Control Subjects. PLoS ONE, 8(5). https://doi.org/10.1371/journal.pone.0061295

Richter, M. F., Storck, M., Blitz, R., Goltermann, J., Seipp, J., Dannlowski, U., Baune, B. T., Dugas, M., \& Opel, N. (2020). Repeated digitized assessment of risk and symptom profiles during inpatient treatment of affective disorder: Observational study. JMIR Mental Health, 7(12). https://doi.org/10.2196/24066

Robotham, D., Satkunanathan, S., Doughty, L., \& Wykes, T. (2016). Do we still have a digital divide in mental health? A five-year survey follow-up. Journal of Medical Internet Research, 18(11). https://doi.org/10.2196/jmir.6511 
medRxiv preprint doi: https://doi.org/10.1101/2021.10.01.21264398; this version posted October 1 , 2021. The copyright holder for this preprint (which was not certified by peer review) is the author/funder, who has granted medRxiv a license to display the preprint in All rights reserved. No reuse allowed without permission.

Rojnic Kuzman, M., Andlauer, O., Burmeister, K., Dvoracek, B., Lencer, R., Koelkebeck, K., Maric, N. P., Nawka, A., Pantovic-Stefanovic, M., Riese, F., Aukst Margetic, B., Bosnjak, D., Ruzic, M. C., Curkovic, M., Grubsin, J., Madzarac, Z., Makaric, P., Petric, D., Radic, K., \& Savic, A. (2018). Effective assessment of psychotropic medication side effects using PsyLOG mobile application. Schizophrenia Research, 192, 211-212. https://doi.org/10.1016/j.schres.2017.04.038

Santesteban-Echarri, O., Piskulic, D., Nyman, R. K., \& Addington, J. (2020). Telehealth interventions for schizophrenia-spectrum disorders and clinical high-risk for psychosis individuals: A scoping review. Journal of Telemedicine and Telecare, 26(1-2), 14-20. https://doi.org/10.1177/1357633X18794100

Sartorius, N. (2014). Patient-reported outcomes in psychiatry. Dialogues in Clinical Neuroscience, 16(2), 123-124. https://doi.org/10.31887/dcns.2014.16.2/nsartorius Soto-Rey, I., Dugas, M., \& Storck, M. (2017). Implementation of an ODM and HL7 compliant electronic patient-reported outcome system. Studies in Health Technology and Informatics, 228, 421-425. https://doi.org/10.3233/978-1-61499-678-1-421

Soto, C. J., \& John, O. P. (2017). Short and extra-short forms of the Big Five Inventory-2: The BFI-2-S and BFI-2-XS. Journal of Research in Personality, 68(February), 69-81. https://doi.org/10.1016/j.jrp.2017.02.004

Steer, R. A., Beck, A. T., Riskind, J. H., \& Brown, G. (1987). Relationships between the Beck Depression Inventory and the Hamilton Psychiatric Rating Scale for Depression in depressed outpatients. Journal of Psychopathology and Behavioral Assessment, 9(3), 327-339. https://doi.org/10.1007/BF00964561

Surmann, M., Bock, E. M., Krey, E., Burmeister, K., Arolt, V., \& Lencer, R. (2017). Attitudes towards using eHealth in psychiatry and psychotherapy: A pilot survey at the DGPPN Congress 2014. Nervenarzt, 88(9), 1036-1043. https://doi.org/10.1007/s00115-0160208-8 
medRxiv preprint doi: https://doi.org/10.1101/2021.10.01.21264398; this version posted October 1, 2021. The copyright holder for this preprint (which was not certified by peer review) is the author/funder, who has granted medRxiv a license to display the preprint in All rights reserved. $N$ perpetuity.

reuse allowed without permission.

Surmann, Marian, \& Lencer, R. (2017). Behandlungsassistenz durch elektronische Medien in der Schizophrenieversorgung. Zeitschrift fur Psychiatrie, Psychologie und Psychotherapie, 65(2), 95-103. https://doi.org/10.1024/1661-4747/a000308

Tobitt, S., \& Percival, R. (2019). Switched on or switched off? A survey of mobile, computer and Internet use in a community mental health rehabilitation sample. Journal of Mental Health, 28(1), 4-10. https://doi.org/10.1080/09638237.2017.1340623

Tolley, C., Rofail, D., Gater, A., \& Lalonde, J. (2015). The feasibility of using electronic clinical outcome assessments in people with schizophrenia and their informal caregivers. Patient Related Outcome Measures, 91. https://doi.org/10.2147/prom.s79348

Too, L. S., Leach, L., \& Butterworth, P. (2020). Mental health problems and internet access: Results from an australian national household survey. JMIR Mental Health, 7(5). https://doi.org/10.2196/14825

Torous, J., \& Baker, J. T. (2016). Why psychiatry needs data science and data science needs psychiatry connecting with technology. JAMA Psychiatry, 73(1), 3-4. https://doi.org/10.1001/jamapsychiatry.2015.2622

Torous, J., Staples, P., Barnett, I., Onnela, J. P., \& Keshavan, M. (2018). A crossroad for validating digital tools in schizophrenia and mental health. npj Schizophrenia, 4(1), 1-2. https://doi.org/10.1038/s41537-018-0048-6

Treisman, G. J., Jayaram, G., Margolis, R. L., Pearlson, G. D., Schmidt, C. W., Mihelish, G. L., Kennedy, A., Howson, A., Rasulnia, M., \& Misiuta, I. E. (2016). Perspectives on the use of eHealth in the management of patients with schizophrenia. Journal of Nervous and Mental Disease, 204(8), 620-629. https://doi.org/10.1097/NMD.0000000000000471

Vaportzis, E., Clausen, M. G., \& Gow, A. J. (2018). Older adults experiences of learning to use tablet computers: A mixed methods study. Frontiers in Psychology, 9(SEP), 1-12. https://doi.org/10.3389/fpsyg.2018.01631

Wildenbos, G. A., Jaspers, M. W. M., Schijven, M. P., \& Dusseljee-Peute, L. W. (2019). 
medRxiv preprint doi: https://doi.org/10.1101/2021.10.01.21264398; this version posted October 1, 2021. The copyright holder for this preprint (which was not certified by peer review) is the author/funder, who has granted medRxiv a license to display the preprint in All rights reserved. No reuse allowed without permission.

Mobile health for older adult patients: Using an aging barriers framework to classify usability problems. International Journal of Medical Informatics, 124(September 2018), 68-77. https://doi.org/10.1016/j.ijmedinf.2019.01.006

Wong, K. T. G., Liu, D., Balzan, R., King, D., \& Galletly, C. (2020). Smartphone and internet access and utilization by people with Schizophrenia in South Australia: Quantitative survey study. JMIR Mental Health, 7(1), 1-10. https://doi.org/10.2196/11551

World Health Organization. (1993). The ICD-10 classification of mental and behavioural disorders: Diagnostic criteria for research. The ICD-10 classification of mental and behavioural disorders: Diagnostic criteria for research, xiii $+248 \mathrm{p}$. 
medRxiv preprint doi: https://doi.org/10.1101/2021.10.01.21264398; this version posted October 1 , 2021. The copyright holder for this preprint (which was not certified by peer review) is the author/funder, who has granted medRxiv a license to display the preprint in

All rights reserved. No reuse allowed without permission.

perpetuity 